\title{
LOCATION OF PLANTED FORESTS INFLUENCING THE WOOD COMMERCIALIZATION IN THE STATE OF GOIAS, BRAZIL
}

\author{
Guilherme Resende Oliveira ${ }^{1}$, Fernando Moreira de Araújo ${ }^{2}$ \\ ${ }^{1}$ UniAlfa e Instituto Mauro Borges de Estatísticas e Estudos Socioeconômicos. Goiânia, Goiás, Brasil. resendego@yahoo.com.br \\ ${ }^{2}$ Universidade Federal de Goiás (UFG). Goiânia, Goiás, Brasil. fernandomsbl@ gmail.com \\ Received for publication: 20/02/2019 - Accepted for publication : 13/11/2020
}

\begin{abstract}
Resumo
As florestas plantadas cresceram substancialmente no Brasil, especialmente em alguns estados, como Goiás, fator que por um lado, compete com áreas de florestas nativas, mas que por outro, se apresenta como soluções economicamente viáveis à recuperação de áreas degradadas. O estudo apresenta o mercado de madeira no estado de Goiás analisando a interação das curvas de oferta e demanda numa análise de equilíbrio parcial. Neste sentido é fundamental entender a questão espacial para oferecer sua produção planejando os custos de transação relacionados ao transporte. Assim, a distribuição de empresas ligadas à sua cadeia de produção é mapeada por meio de bases de mercado de trabalho (Rais/TEM), da produção de madeira (Pesquisa da Produção da Extração Vegetal e da Silvicultura/IBGE) e outros dados do setor. A análise espacial da área de floresta plantada (silvicultura) em Goiás entre 2000 e 2016 foi baseada em dados de séries temporais, dos mapeamentos fornecidos pelo Projeto MapBiomas. Apenas em Goiás, considerando todos os setores da cadeia produtiva florestal, em 2015, o faturamento ultrapassou R \$ 4,1 bilhões (US\$ 1,24 bilhões) e a arrecadação pública, R\$ 79 milhões, empregando mais de 36 mil pessoas em 7 mil empresas. Assim, é fundamental entender esse processo, identificando os principais determinantes das florestas plantadas, por meio de análises estatísticas e espaciais. Do ponto de vista espacial, as florestas plantadas e as empresas ligadas à produção madeireira estão relativamente espalhadas pelo estado, com exceção da região metropolitana de Goiânia, que concentra um grande número firmas de comércio e fabricação de madeira.

Palavras-chave: floresta plantada, cadeia produtiva, análise espacial.
\end{abstract}

\begin{abstract}
Planted forests have grown substantially in Brazil, especially in states such as Goias. While they may compete with native forest areas, planted forests also present themselves as economically viable solutions for the recovery of degraded areas. This study presents the market of wood in the Brazilian state of Goias analyzing the interaction between supply and demand curves of the product in a partial equilibrium analysis. In this sense, it is essential to understand the spatial issue to offer production by planning the transaction costs related to transportation. Therefore, the distribution of companies is linked to the production chain, mapped by means of labor market bases (Ministry of Labor), wood production (IBGE) and other industry data. The spatial analysis of the planted forest area (silviculture) in Goias between 2000 and 2016 was based on data from the time series, from mapping provided by the MapBiomas Project. In Goias, considering all sectors of the forest production chain, in 2015 alone, revenues exceeded US\$ 1.24 billion and public collections US\$ 24 million, employing more than 36 thousand people in 7 thousand firms. Thus, it is fundamental to understand this process, identifying the main determinants of planted forests, through statistical and spatial analysis. From a spatial point of view, planted forests and companies involved in wood production are relatively spread throughout the state, except for the state capital of Goiania, which has a large number of timber trade and manufacturing firms. Keywords: planted forest, production chain, spatial analysis.
\end{abstract}

\section{INTRODUCTION}

Brazil is one of the main holders of abundant forest resources. The country has the second largest forest cover in the world. The Ministry of the Environment (MMA) estimates that most of this coverage has productive potential. As a result, the country has developed a complex productive structure in the forest sector, including planted forests, especially with pine and eucalyptus trees (SFB, 2017). Even so, only $0.9 \%$ of its area is occupied by planted forests (IBA, 2015).

According to data from the research on Vegetable Extraction and Silviculture Production (PEVS) of the Brazilian Institute of Geography and Statistics (IBGE), Goias has had a relevant production in the national context of firewood, but has not in charcoal, timber and other silvicultural productions. The state has an area of 144,049 thousand hectares of planted area, equivalent to $0.42 \%$ of Goias's total territory and $1.4 \%$ of the total area of Brazilian planted forests (IBGE, 2017). In 2017, the state produced 3.4 million cubic meters of firewood, equivalent to $6.3 \%$ of the national production, specifically in eucalyptus firewood.

FLORESTA, Curitiba, PR, v. 51, n. 2, p. 320-328, abril/jun 2021.

Oliveira, G. R. et.al.

ISSN eletrônico 1982-4688

DOI: $10.5380 /$ rf.v51 i2. 65087 
There are two models of industrial organization in the forest sector in Brazil. On the one hand, especially in the pulp, paper, wood pulp, fiberboard and agglomerated wood sectors, the sector is dominated by a few large companies, vertically integrated from the forest to finished products, from production to trade. On the other hand, mainly in the production of sawn, plywood and furniture, there is a large number of small and medium-sized companies with lesser business capacity. In the case of the furniture industry, in addition to the variety in the use of materials, the sector represents a strong pulverization of consumer preferences, leading to a reduction in the scale of demand and significant market fragmentation (SFB, 2017).

For the producer to achieve a favorable financial situation, it is fundamental to understand some economic aspects of their business. Economics are determined by the interaction between supply and demand curves of the product in a partial equilibrium analysis. This study seeks to deal with these curves, with an emphasis on the demand side. After all, it is understood that producers need to understand the market, including the territorial issue (location) to offer their production and to plan transaction costs related to transportation.

Santos and Santana (2009) analyzed the behavior of the wood forestry sector in Para (Brazil) from 1998 to 2004. They used locational methodologies with the same database (RAIS) as this study to identify 25 municipalities specialized in wood and furniture activities according to 5 distinct forestry activities. Robert et al. (2011) diagnosed the quantity and origin of commercialized sawn wood in Florianopolis-SC, highlighting volume, species, provenance and the average distance from the main suppliers to the consumer market. Castro et al. (2012) emphasized the need to analyze the dimension and planning of production, reducing risks and uncertainties of commercialization. They show an econometric model to predict the flow of sawn wood in Brazil. This study aims to analyze the market of wood in the Goias state, through the distribution of capital companies to their production chains, mapped by labor market bases and wood production, as well to territorially examine the reforestation production for the timber processing and consumer markets.

In addition, it is important to emphasize some particularities of the wood market. Silva et al. (2014) shows that $75 \%$ of the sellers analyzed in the study do not know how to correctly indicate certified products. Besides merely not knowing the stamps and proper identification processes, they do not understand the necessary concepts, legal milestones and rarely engage in environmental projects or campaigns for the use of certified wood. Even so, there is ample potential for the dissemination of increased certification and marketing knowledge of these products.

Most of the studies that deal with wood extraction address aspects within the gateway, such as diagnosis, installation and management. However, it is known that one of the most important steps related to the project concerns the commercialization of production. Wood production has a long elaboration period throughout its production chain and producers often have little market experience.

The study presents a picture of areas with planted forests and spatial distribution of companies engaged in logging in the state of Goias using data published by governmental organizations and non-governmental organizations (MapBiomas project). It shows the wood market in the state of Goias using the distribution of companies linked to the production chain, suggested by SFB (2020) and mapped according to the Annual Report of Social Information (RAIS) of the Ministry of Labor and Employment (MTE), the production of wood according to the Production Survey Plant Extraction and Silviculture (PEVS / IBGE), and other data from the sector, such as the production of logging by CNAE (National Classification of Economic Activities).

\section{MATERIAL AND METHODS}

The forest-based product industry is complex and has several niche markets. Brazil (2007) shows that the Brazilian Association of the Mechanically Processed Wood Industry (Abimci) divides this industry into three sectors: sawn wood, plywood and wood. Therefore, we adopted a methodology to define the production chain objective of this study according to the SFB 2020) which states: "the production chain is a set of consecutive stages through which it passes and starts to be transformed and transferred by several inputs since a pre- production until the final consumption of a good or service". In this way, an institution defines the activities related to forest production, enabling the selection of related activities in the CNAEs, used by IBGE. In this case, sectors related to timber products were considered, both from planted and native forests, such as firewood, charcoal, sawn wood, cellulose, solid and processed wood. The activities related with non-timber products were excluded, such as the chemical, pharmaceutical, food industry, and others.

FLORESTA, Curitiba, PR, v. 51, n. 2, p. 320-328, abril/jun 2021. 
The spatial analysis of the area of planted forest (silviculture) in Goias between 2000 and 2016 was based on data from the time series, mappings provided by the MapBiomas Project. The MapBiomas project is an initiative of public and private institutions that has the objective of mapping land use and natural vegetation coverage throughout the national territory, considering the basis for the availability of data on the Brazilian biome limit, i.e. Amazonia, Caatinga, Cerrado, Atlantic Forest, Pampa and Pantanal. Currently, land use data is available from 2000 to 2016 (MAPBIOMAS, 2017). In addition, this is the only map with full coverage of the state of Goias with annual information. The MapBiomas mapping is performed using Landsat satellite images (5, 7 and 8) using timeseries and spectral indexes processing and automatic classifiers and machine learning) pixeled for each Brazilian biome (MAPBIOMAS, 2017). MapBiomas follows the logic of data availability as performed by NASA, i.e. by collections

Based on MapBiomas for Goias, the area of forest planted by PEVS (IBGE) between 2014 and 2016 (period available in the survey) was used for the comparative analysis of the planted areas in Goias. The Survey on the PEVS provides statistical information on the quantity and value of the productions obtained from the exploitation of natural forest resources, called plant extractivism, as well as from the exploitation of planted forest masses (silviculture). The total area and area harvested from forest crops are provided by this research. The methodology used to collect information basically is the application of a questionnaire for each municipality in the country. The agent collects the information by consulting agricultural establishments, industries and other bodies active in the sector. The collection of information consists of periodic consultations with the sources, allowing the systematic monitoring of the exploitation of forest resources (IBGE, 2016).

This public base compilation is important due to the complementarity of mappings and several methodologies, the classification of orbital images and census surveys at the property level, can contribute to the refinement of the areas of planted forest to Goias and its municipalities.

Altogether, Goias has more than 7 thousand companies and 36 thousand jobs in the activities related to the commercialization and production of wood products, or that uses it as an input. Although the greater number of jobs and companies are linked to the commercialization, the beginning of the chain is one of the most important phases of the market, after all, the cost of production of this stage is reflected in the prices of the final products and, consequently, affects the entire market of products in the state.

\section{RESULTS}

The areas of planted forest grew in the state of Goias between 2000 and 2016, according to MapBiomas mapping, was $\cong 9,800 \%$, occupying an area of 707 ha to 69,000 ha. However, this increase showed four cycles of growth of planted area, the first from 2000 to 2004, occupied area stabilized; from 2005 to 2009, an increase of $\cong$ $330 \%$ of the area in relation to the first cycle (770 to 2641 ha); from 2010 to 2013, the sector gained more representation and production becomes more profitable, presenting an increase of $\cong 1,200 \%$ (2,641 to 32,200 ha). The increase in the area of planted forest was probably due to the greater demand in the sector, a fact that occurred in parallel. Finally, between 2014 and 2016, we have two moments, in 2014, an increase of $\cong 220 \%(32,200$ to $71,641 \mathrm{ha})$ and a fall of $8.2 \%$ in the area planted between 2015-2016, currently occupying 69,000 ha in Goias's territory (Figure 1). 

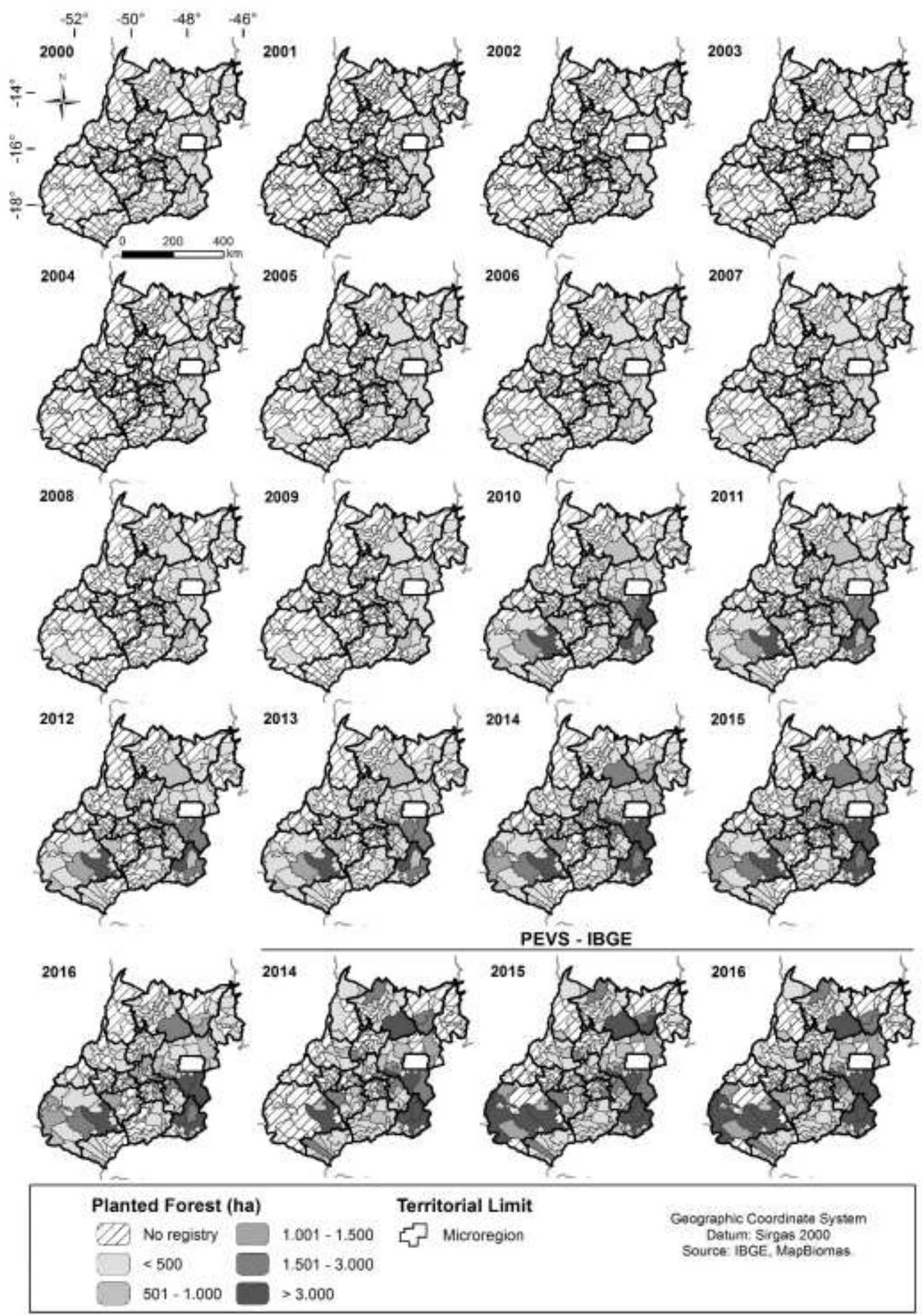

Source: MapBiomas (2000 - 2016).

Figure 1 - Distribution of planted forest area (ha) in Goias between 2000 and 2001

Figura 1 - Distribuição da área de floresta plantada (ha) em Goiás entre 2000 a 2001

Among the 246 municipalities in the state of Goias, 46 registered zero registered hectares of planted trees in 2016, according to data collected from the PEVS, with municipalities of Catalão (9.7\%), Ipameri (9\%), Niquelândia (7.7\%), Rio Verde (7.6\%) and Campo Alegre de Goias (94.2\%) recorded the largest areas in Goias, respectively.

FLORESTA, Curitiba, PR, v. 51, n. 2, p. 320-328, abril/jun 2021. 

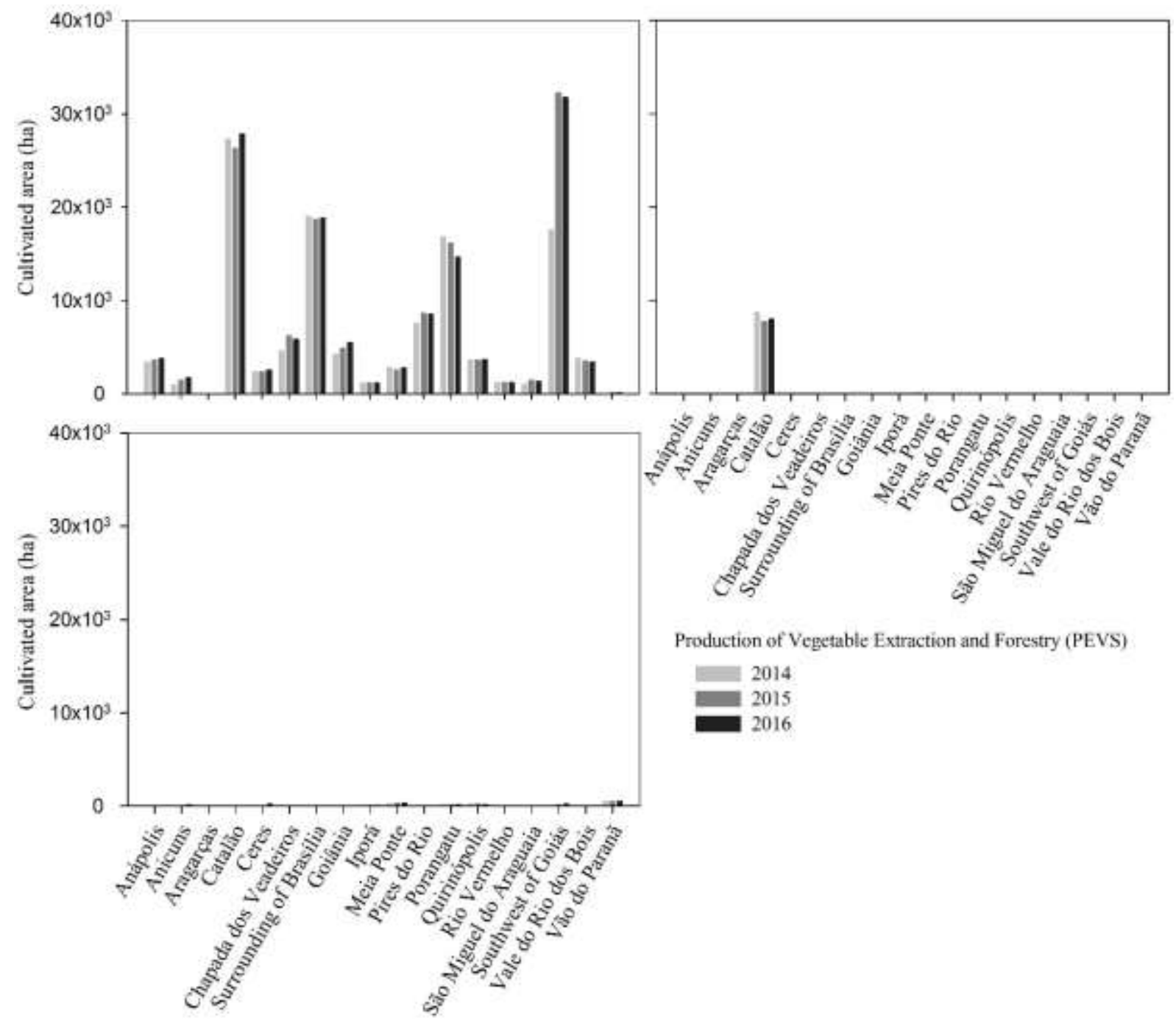

Source: PEVS/IBGE

Figure 2 - Distribution of forest area planted by forest species in Goias

Figura 2 - Distribuição da área de floresta plantada por espécie florestal em Goiás

The forest species with the largest planted area in Goias in 2016, according to the PEVS, are Eucalyptus and Pinus, occupying $93.1 \%$ and $5.7 \%$, respectively (Figure II). In order to maintain the proportionality of the production of the presented species, the same scales were maintained in the previous graph. The variation of planted area between species between 2014 and 2016 was positive for eucalyptus (14\%) and other species (45.2\%), while pine production showed a decrease of $8 \%$, being replaced by species such as rubber tree and teak. A study by Reis et al. (2017) shows that Goias has an estimated planted forest area of 186,912 ha, with eucalyptus being the most representative species, occupying $85 \%(159,225.41 \mathrm{ha})$ of the plantations, followed by the rubber tree (11\% - 20,802, 80 ha) and Pinus (3.6\% - 6,883.87 ha). According to this study, eucalyptus presents greater adaptability to the climate and soils of the Cerrado, fast growth, cycles of short rotation and use for different uses.

The Ministry of Labor (MTE) has registered all formalized companies in Brazil by type of activity. For this analysis, companies were selected according to the National Classification of Economic Activities (CNAE) that had their activities related to wood, such as commercialization, manufacturing and transformation. In this sense, we highlight the divisions 16, 31 and 46, respectively: manufacturing of wood products; furniture manufacturing; and wholesale trade, except motor vehicles and motorcycles. Within these divisions, the main groups were selected that have relationships with the planted forests.

Data from SEFAZ (2015) shows that the billing of the sectors of furniture manufacturing and wood products manufacturing was $\mathrm{R} \$ 1.03$ billion and $\mathrm{R} \$ 118$ million, respectively, with a total collection of more than $\mathrm{R} \$ 43$ million (Table 1). Therefore, these sectors move the market and are highly profitable for the state

FLORESTA, Curitiba, PR, v. 51, n. 2, p. 320-328, abril/jun 2021.

Oliveira, G. R. et.al.

ISSN eletrônico 1982-4688

DOI: $10.5380 /$ rf.v51 i2. 65087 
government. Considering all sectors of the forest production chain, revenues exceeded $\mathrm{R} \$ 4.1$ billion and collection exceeded R 79 million in 2015. The RAIS data for 2016, in the table below, also shows the size of the sector.

Table 1 - Number of companies and jobs by selected group

Tabela 1 - Número de empresas e empregos por grupo selecionado

\begin{tabular}{l|c|c}
\hline CNAE Group & Number of firms & N. of employees \\
\hline Wood splitting & 34 & 178 \\
\hline Manufacture of wood and articles of wood & 164 & 1.116 \\
\hline $\begin{array}{l}\text { Manufacture of furniture } \\
\text { material and construction material }\end{array}$ & 863 & 7.421 \\
\hline Retail sale of construction materials & 445 & 3.305 \\
\hline Total & 5.496 & 24.965 \\
\hline
\end{tabular}

Source: RAIS (2015).

Several companies and activities, besides those presented here, demand wood as one of the production inputs. However, this survey highlighted only the main companies that use this product. Thus, the map with the number of companies of the selected activities per municipality is presented below, according to the data of the National Classification of Economic Activities (CNAE).

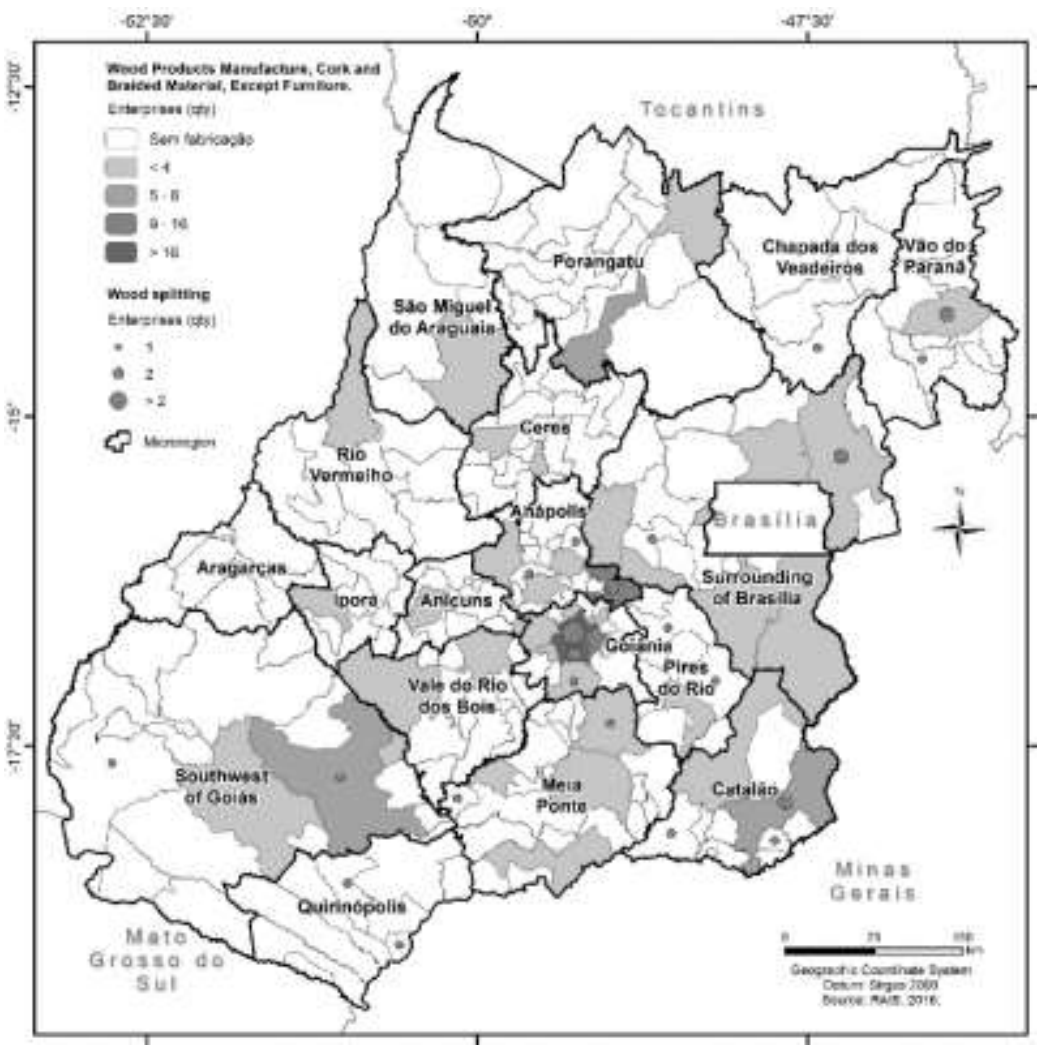

Source: RAIS (2016).

Figure 3 - Distribution of the number of wood manufacturing and wood processing companies (left) and firms related to the wholesale and retail trade of wood (right) in Goias for 2016.

Figura 3 - Distribuição do número de empresas de fabricação de madeira e de desdobramento de madeira empresas vinculadas (esquerda), e de comércio atacadista e varejista de madeira (direita) em Goiás para o ano de 2016.

FLORESTA, Curitiba, PR, v. 51, n. 2, p. 320-328, abril/jun 2021. 


\section{DISCUSSION}

The supply of legalized wood is now one of the main difficulties of the forestry sector, especially in the Amazon region. However, the Cerrado also suffers from illegal deforestation. In this perspective, the deforestation (area) of the natural vegetation in Goias, according to data collected by the Forest Reference Emission Level (FREL) for reducing emissions from deforestation in the Cerrado biome of Ministry of the Environment (MMA) (BRAZIL, 2017), between 2013 and 2015 was 195,369 ha, while the variation of the planted area of forestry in the same period was 37,544 ha (120\% / period) and 16,067 ha (12.6\% / period) in relation to the mapping produced by the MapBiomas project and PEVS, respectively. The linear correlation between deforested / FREL and silviculture areas between Goias municipalities was low, both in relation to the survey conducted by MapBiomas $\left(\mathrm{r}^{2}=-0.023\right)$ and IBGE PEVS $\left(\mathrm{r}^{2}=0.032\right)$.

However, the mapping produced by Hansen et al. (2013), monitoring of the loss and gain of vegetation of more than five meters in height (i.e. natural forests or plantations in the whole range of crown densities), not being characterized as deforestation, shows that forest loss in Goias between 2001 and 2016 was 1,205.289 ha. Whereas, when this data was compared to the relative period of the PEVS survey, the loss was 242,073 ha, or 68\% higher than the planted area of silviculture registered by the IBGE. The spatial correlation of the Hansen et al. data and PEVS / IBGE was also low $\left(\mathrm{r}^{2}=0.07\right)$, and forest loss $(>1 \mathrm{ha})$ was recorded in all municipalities in Goias, while silvicultural practice is registered in 154 municipalities.

Therefore, it is proven that deforestation and/or forest loss in Goias occurs in a diffuse and parallel economic practice of reforestation among its municipalities, especially in those with the smallest records of planted area for forestry. Forestry plantation activity presents a boost to municipal economies, but it could also reinforce instruments such as Payment for Environmental Services (PSAs) (Law 12.512/11) and the Green Grant Program (Decree 7.572 / 11) for the environmental conservation of ecosystems. Studies point to edafoclimatic conditions favoring the development of this activity in all regions of the state (REIS ET AL., 2015). Wood deforestation activity is the first effective stage of timber industrialization (Figure III). In addition, some wood product manufacturing companies also transform them into basic inputs. Only selected activities have improved the economy of several regions of the state, highlighted in certain municipalities whereforestry activity has great importance.

Figure III shows the municipalities that own companies that commercialize wood. The activities of commerce that use wood, both wholesale and retail, are well distributed territorially throughout the state. It should be noted that some of these companies "work the wood", adding value and, consequently, create another market for the wood producer.

The map also reveals that most municipalities in the state (204) do not have the capacity to absorb the raw wood. Thus, it is necessary for the producer to move to one of the municipalities highlighted in the map above. Therefore, there is a transportation cost that must be incorporated into the total costs of the enterprise. For example, if a producer in Doverlandia wants to sell its product, the municipality that owns the nearest market in the state of Goias is Ipora, more than $200 \mathrm{~km}$ from the origin.

On the supply side, the following map presents the production of the two main silvicultural products of the state: logging and firewood (Figure 4). Thus, it is exactly this production that must be shifted to the locations presented in the previous maps. 


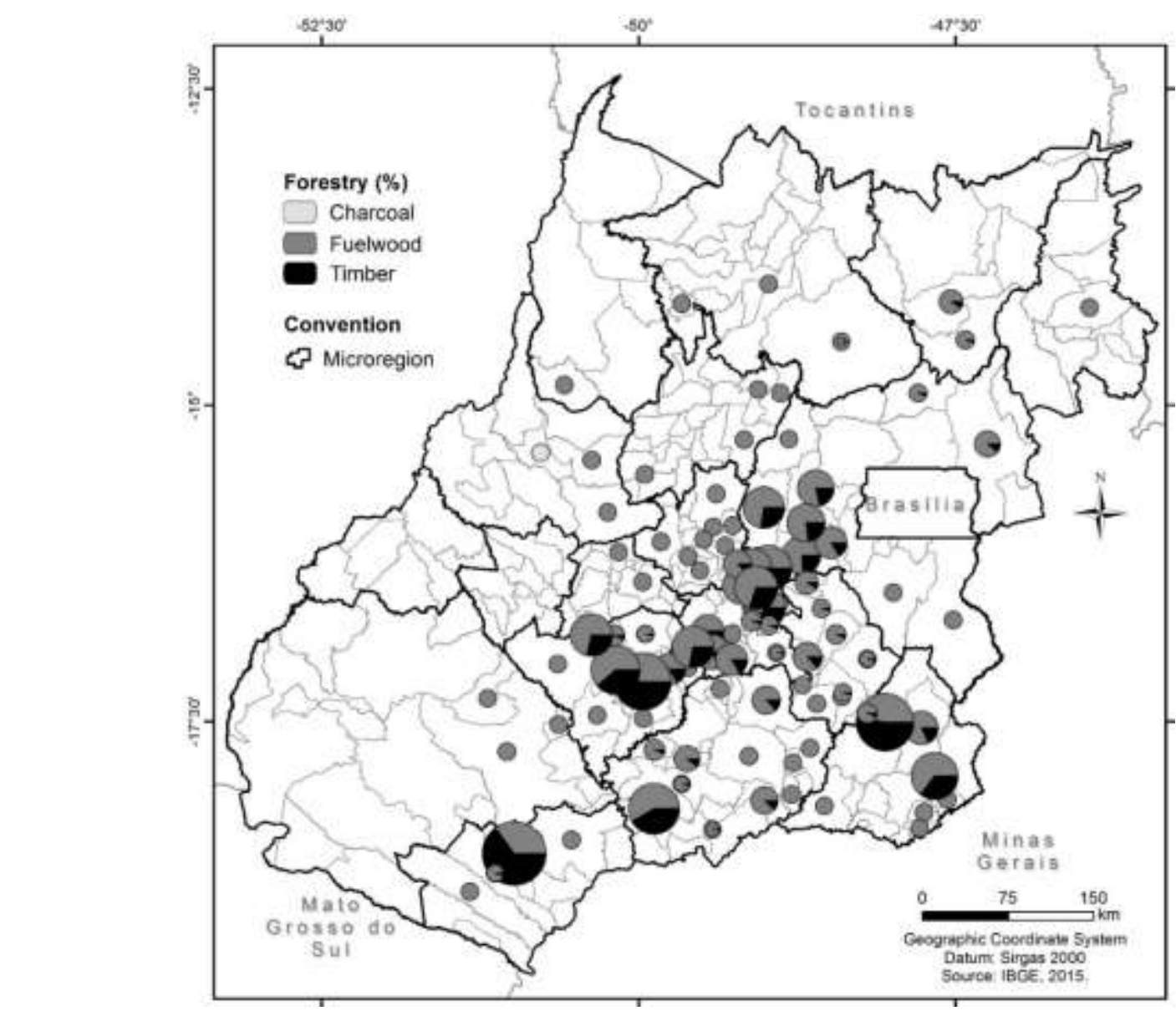

Source: IBGE (2015).

Figure 4 - Distribution of timber and timber production (2015) in Goias.

Figura 4 - Distribuição da produção de lenha e madeira em tora (2015) em Goiás.

\section{CONCLUSIONS}

- Although Goias does not have a significant production of timber, it has a significant production of firewood. In this sense, these activities have an important weight in the economy of some regions of the state. Thus, the action of the public sector is fundamental to further develop the sector and its chains in certain localities. However, it is necessary to understand this market better, in order to facilitate the access of this production, as well as to minimize the costs of displacement of the producers.

- The study reveals that most municipalities in the state do not have the capacity to absorb the raw wood. Thus, it is necessary for the producer to move to another municipality, such that there is a transportation cost that must be incorporated into the total costs of the enterprise. But, among the main fragilities and deficiencies of forestry in Goias are the logistics for cutting and transportation; lack of chain planning; low managerial maturity; etc. Among the challenges are: to create organization and political representation for the production chain; define state policy for forest development; promote the training of producers; and others. It is worth mentioning that the different levels of government, have a great responsibility to assist in the accomplishment of the objectives listed above.

- All the wood supply in Goias today comes from monocultures. This does not mean that there is no market for mixed activities, like ILPF (Agricultural-Livestock-Forest Integration), this wood can be provided since adequate forestry practices are performed on the tree component in that system. One example concerns the furniture industry, where wood quality is a relevant variable. However, this information is not always disseminated at promotional events, where many foresters start plantations of eucalyptus species that are not used for the production of furniture and, consequently, decrease their chances of commercialization in the future. 


\section{REFERENCES}

BRAZIL. Ministry of the Environment (MMA). Brazil's Forest Reference Emission Level for Reducing Emissions from Deforestation in the Cerrado biome for Results-based Payments for REDD+ under the United Nations Framework Convention on Climate Change. Group of Technical Experts on REDD+ (GTT REDD+). Brasília: 2017. 78p. Available in: < http://redd.mma.gov.br/pt/infohub>. Accessed: may, 2018.

BRASIL. Ministério da Agricultura, Pecuária e Abastecimento. Cadeia produtiva de madeira. Ministério da Agricultura, Pecuária e abastecimento, Secretaria de Política Agrícola, Instituto Interamericano de Cooperação para a Agricultura; coordenadores Antonio Márcio Buainain e Mário Otávio Batalha. - Brasília : IICA : MAPA/ SPA, 2007.

CASTRO, R. V. O.; MENDES, A. F. N.; ATAÍDE, G. M.; ARAÚJO JÚNIOR, C. A.; MARCATTI, G. E.; SILVEIRA, D. P. COSTA, C. B. Análise econométrica da produção de madeira serrada no Brasil. Revista Floresta, Curitiba, PR, v. 42, n. 4, p. 661 - 670, out./dez. 2012.

EMBRAPA. Available in: <https://www.embrapa.br/en/busca-de-produtos-processos-e-servicos/-/produtoservico/1049/sistemas-de-producao-integrados---ilpf >. Accessed in: sep. 2017a.

Available in: https://www.embrapa.br/tema-integracao-lavoura-pecuaria-floresta-ilpf/nota-tecnica. Accessed in: sep. 2017.

INSTITUTO BRASILEIRO DE GEOGRAFIA E ESTATÍSTICA - IBGE. Produção da Extração Vegetal e da Silvicultura - 2016. Available in: < https://sidra.ibge.gov.br/pesquisa/pam/tabelas〉. Acessed: Feb. 2018.

HANSEN, M. C.; POTAPOV, P. V.; MOORE, R.; HANCHER, M.; TURUBANOVA, S. A.; TYUKAVINA, A.; THAU, D.; STEHMAN, S. V.; GOETZ, S. J.; LOVELAND, T. R.; KOMMAREDDY, A.; EGOROV, A.; CHINI, L.; JUSTICE, C. O.; TOWNSHEND, J. R. G. High-Resolution Global Maps of 21st-Century Forest Cover Change. Science, vol. 342, p.850-53, 2013. Data available from: <earthenginepartners.appspot.com/science-2013-globalforest>. Acessed on Global Forest Watch: feb. 2018.

INDÚSTRIA BRASILEIRA DE ÁRVORES - IBA. Relatório IBÁ 2015. Available in: < http://iba.org/images/shared/iba_2015.pdf > Accessed: september, 2018.

MAPBIOMAS. Algorithm Theoretical Base Document \& Results (ATBD_R). MapBiomas General Handbook, Version 2. 2017.

MINISTÉRIO DO TRABALHO E EMPREGO - MTE. Relação Anual de Informações Sociais - RAIS. 2016. Available in: <http://pdet.mte.gov.br/acesso-online-as-bases-de-dados>. Accessed in: sep. 2017.

REIS, C. A. F.; MORAES, A. da C.; PEREIRA, A. V.; AGUIAR, A. V. de; SOUSA, V. A. de; BORGES, H. M. D. Diagnóstico do setor de florestas plantadas no Estado de Goias. Brasília, DF: Embrapa, 2015. 139 p.

REIS, C.; TALONE NETO, A.; BRUNCKHORST, A.; MOREIRA, J.; PEREIRA, A.; MORAES, A. Cenário do Setor de Florestas Plantadas no Estado de Goias. Colombo (PR): Embrapa Florestas; S.1.: SEBRAE, 2017.

ROBERT, R. C. G.; SANTOS, A. S.; SANTOS, L. D.; FANTINI, A. C. Caracterização do abastecimento de madeira serrada comercializada no município de Florianópolis-SC. Revista Floresta, Curitiba, PR, v. 42, n. 1, p. 85 - 94, jan./mar. 2012.

SANTOS, R.; SANTANA, A. Comportamento recente do setor florestal madeireiro no estado do Pará, Brasil. Revista Árvore, Viçosa-MG, v.33, n.3, p.533-543, 2009.

SECRETARIA DA FAZENDA DO ESTADO DE GOIAS - SEFAZ. Informações sobre entradas e saídas de recursos das empresas, 2016.

SERVIÇO FLORESTAL BRASILEIRO - SFB. Produção florestal. ND. Available in: <http://www.florestal.gov.br/snif/producao-florestal/cadeia-produtiva>. Accessed in: set. 2017.

SERVIÇO FLORESTAL BRASILEIRO - SFB. Sistema Nacional de Informações Florestais. Cadeia Produtiva, 2020. Disponível em: < http://snif.florestal.gov.br/pt-br/cadeia-produtiva >

SILVA, D. M.; ARAÚJO, M. C.; SILVA, V. F.; BERNARD, E. Contradições no comércio de madeira certificada em uma região metropolitana do Nordeste do Brasil. Revista Floresta, Curitiba, PR, v. 42, n. 4, p. 661 - 670 , out./dez. 2012.

FLORESTA, Curitiba, PR, v. 51, n. 2, p. 320-328, abril/jun 2021 